\title{
МОДЕЛЬ ФОРМУВАННЯ ДОСЛІДНИЦЬКОЇ КОМПЕТЕНТНОСТІ МАЙБУТНІХ ФЕЛЬДШЕРІВ У ПРОЦЕСІ ВИВЧЕННЯ БІОЛОГІЧНИХ ДИСЦИПЛІН
}

\author{
A. R. Moseychuk \\ Odesa Regional Basic Medical School

\section{MODEL OF FUTURE FELDSHER'S RESEARCH COMPETENCY FORMATION DURING ACADEMIC BIOLOGICAL SUBJECTS STUDYING PROCESS}

\begin{abstract}
Мета дослідження - науково обгрунтувати модель формування дослідницької компетентності майбутніх фельдшерів у процесі вивчення біологічних дисциплін.

Матеріали та методи дослідження. Формування дослідницької компетентності майбутніх фельдшерів у процесі вивчення біологічних дисциплін не стихійний, а керований і регульований процес, результативність та успішність якого залежать від визначених педагогічних умов, які реалізовано через засоби, методи і форми навчального процесу. Групи методів склали: методи, що формують науковий світогляд майбутніх фельдшерів і здійснюють обмін інформацією (бесіда, диспут, есе); методи, що організують дослідницьку діяльність майбутніх фельдшерів і стимулюють її мотиви (дослід, інструктаж, дослідницькі завдання, ділова гра, проектний метод, кейс-метод); методи, що надають допомогу майбутнім фельдшерам здійснювати рефлексію їх дослідницької діяльності (індивідуальна бесіда, есе). Основними формами організації навчання виступили: лекції, семінаридискусії, лабораторно-дослідні заняття, олімпіади, круглий стіл, конференція, майстер-клас, самостійна робота, практика, робота у науковому гуртку, індивідуальні консультації.

Результати й обговорення. Дослідницька компетентність забезпечує безперервний саморозвиток особистості протягом всього життя у соціальній і професійній сферах завдяки системним трансдисциплінарним знанням методології та парадигматики наукового дослідження, вмінню всебічно, критично, економно опрацьовувати найновішу інформацію і мобільно використовувати її для розв’язання професійних задач. Аналіз педагогічної літератури засвідчує, що процес моделювання широко застосовується в педагогіці й дидактиці. При цьому моделюванню підлягає як зміст освіти, так і навчальна діяльність. Для відображення цілісної картини досліджуваного процесу розроблено структурно-змістову модель формування дослідницької компетентності майбутніх фельдшерів у процесі вивчення біологічних дисциплін. Розробляючи педагогічну модель, дійшли висновку, що проблема формування дослідницької компетентності майбутніх фельдшерів у процесі вивчення біологічних дисциплін $є$ складною і різнобічною, яку потрібно розглядати з позицій системного та компетентнісного наукових підходів.

Висновки. Моделювання процесу формування дослідницької компетентності відповідно до концепцій системного та компетентнісного підходів забезпечить позитивну динаміку рівнів сформованості дослідницької компетентності майбутніх фельдшерів. Подальший науковий пошук спрямовано на визначення ефективності розробленої моделі та педагогічних умов формування дослідницької компетентності майбутніх фельдшерів у процесі вивчення біологічних дисциплін.
\end{abstract}

Ключові слова: майбутні фельдшери; дослідницька компетентність; формування; структурно-змістова модель.

The aim of the study - scientifically justifying the model of the research competence of the future medical assistants in the study of biological sciences.

Materials and Methods. Formation of research competence of paramedics in the study of biological sciences do not spontaneous but controlled and regulated process effectiveness and success of which depends on the determined pedagogical conditions are realized through the means, methods and forms of educational process. Groups of methods consisted of: methods that form the scientific outlook of future paramedics and exchanges information (conversation, debate, essay); methods to organize research activities for future paramedics and stimulate its reasons (research, instruction, research objectives, role play, project method, case method); methods of assisting prospective paramedics of reflection implement their research activities (individual interviews, essays). The main forms of organization of training were lectures, seminars, discussions, laboratory research studies, competitions, roundtable conference, workshop, self-study, practice, work in scientific circles, individual consultations.

Results and Discussion. Research expertise provides continuous self-development of the individual for the whole life in the social and professional spheres through systematic transdisciplinary knowledge of methodology and paradigmatics of scientific research, ability to comprehensively, critically, economically handle the latest information and use it mobile to solve problems of professional tasks. Analysis 
of pedagogical literature shows that the process of modeling is widely used in pedagogy and didactics. Thus, educational content as well as learning activities are subject to modeling. To display a complete picture of the studied process there have been developed structural and semantic model of the research competence of the future medical assistants in the study of biological sciences. Developing pedagogic model it should be concluded that the problem of forming of research competence of the future medical assistants in the study of biological sciences is complex and diverse, which should be considered from the standpoint of system competence and scientific approaches.

Conclusions. Simulation of the formation of research competence in accordance with the concepts of system and competence approach will ensure the positive dynamics of the levels of research competence of the future medical assistants. Further scientific research is aimed at determining the effectiveness of the model developed and pedagogical conditions of formation of research competence of the future medical assistants in the study of biological sciences.

Key words: future medical assistants; research competence; formation; structure and conceptual model.

Вступ. Аналіз практики підготовки фахівців у медичних навчальних закладах переконує в недостатній ефективності традиційного типу навчання щодо підвищення якості підготовки фахівців через притаманний йому інформаційно-догматичний метод організації викладання. Сучасна медична освіта вимагає розвитку самостійності майбутніх фахівців, яка формується, насамперед, у дослідницькій діяльності. Сучасна педагогічна практика цьому надає великого значення. Водночас дослідники звертають увагу на недостатність теоретичної обгрунтованості проблеми формування дослідницької компетентності майбутніх медичних фахівців і технологічної забезпеченості цієї складової освітнього процесу, а також низьку її ефективність.

Мета дослідження - науково обгрунтувати модель формування дослідницької компетентності майбутніх фельдшерів у процесі вивчення біологічних дисциплін.

Матеріали та методи дослідження. Формування дослідницької компетентності майбутніх фельдшерів у процесі вивчення біологічних дисциплін не стихійний, а керований і регульований процес, результативність та успішність якого залежать від визначених педагогічних умов, які реалізовано через засоби, методи і форми навчального процесу. Групи методів склали: методи, що формують науковий світогляд майбутніх фельдшерів і здійснюють обмін інформацією (бесіда, диспут, есе); методи, що організують дослідницьку діяльність майбутніх фельдшерів і стимулюють її мотиви (дослід, інструктаж, дослідницькі завдання, ділова гра, проектний метод, кейс-метод); методи, що надають допомогу майбутнім фельдшерам здійснювати рефлексію їх дослідницької діяльності (індивідуальна бесіда, есе). Основними формами організації навчання виступили: лекції, семінаридискусії, лабораторно-дослідні заняття, олімпіади, круглий стіл, конференція, майстер-клас, самостійна робота, практика, робота у науковому гуртку, індивідуальні консультації.
Результати й обговорення. Аналіз наукових джерел з означеної проблеми дозволив виокремити напрями дослідження: сутність компетентнісного підходу до професійної підготовки майбутніх фахівців (І. Бех, О. Бігич, О. Бірюк, А. Волкова, О. Волошина, О. Глузман, М. Головань, О. Демчук, М. Євтух, Ю. Зіньковский, М. Князян, А. Локшина, В. Луговий, О. Онопрієнко, С. Сисоєва, О. Спірін, М. Степко, Л. Хоружа, К. Хударковський та ін.); теоретичні засади організації науково-дослідницької діяльності студентів (Є. Барбіна, Г. Васянович, О. Глузман, В. Гриньова, Н. Кічук, М. Князян, В. Козаков, 3. Курлянд, С. Литвиненко, В. Майборода, Г. Нагорна, О. Пєхота та ін.); науково-дослідницька діяльність як чинник підвищення якості професійної підготовки студентів (Т. Алієв, Д. Богоявленська, О. Воленко, Н. Романенко, С. Скворцова, С. Жура та ін.).

Вирішенню означених проблем сприяють наявні в педагогічній науці підходи, що базуються на психологічній теорії навчальної діяльності (П. Гальперін, В. Давидов, А. Маркова, Н. Тализіна, Д. Ельконін, І. Зимня, І. Лернер), у якій, з одного боку, розкрито механізми розвитку самостійності та активності особистості, а з іншого - виявлено природу і специфіку дослідницької діяльності та складники ії навчальних дій.

Сучасна медична освіта не повною мірою виправдовує соціальні та особистісні очікування. Випускники медичних коледжів у переважній більшості не $є$ активними, самостійними носіями і трансляторами цінностей, накопичених та інтеріоризованих у цій сфері професійної діяльності. Це істотно обмежує перенесення сформованих дослідницьких компетенцій на культуру навчальної та професійного діяльності, хоча $€$ вітчизняні дослідження з проблеми організації навчальної діяльності в медичних коледжах (Л. Дольнікова, Г. Матвійченко, В. Пінькас, М. Трегубенко), виховної роботи (Х. Мазепа), використання комп’ютерних технологій (Л. Артемчик, I. Булах та ін.). 
Отже, теоретичний аналіз наукових джерел засвідчив, що проблема формування дослідницької компетентності майбутніх фельдшерів у процесі вивчення біологічних дисциплін дотепер не стала предметом спеціального науково-педагогічного дослідження i, по суті, в межах теорії і методики професійної освіти ще не знайшла свого належного теоретичного обгрунтування.

Необхідність моделювання процесу формування дослідницької компетентності майбутніх фельдшерів у процесі вивчення біологічних дисциплін визначається потребою практики професійної освіти в побудові цього процесу, виділенні його базових компонентів, моніторингу результатів, отримання інформації про можливості його вдосконалення.

Як відомо, модель - це штучно створений об’ єкт, який передає будь-які суттєві особливості оригіналу, відображаючи в більш простому вигляді його структуру і взаємозв’язки між його компонентами. У науковій літературі смислове поле поняття “модель” визначається як: пристрій що відтворює, імітує будову, функції, дії будь-якого іншого пристрою (при випробуваннях); образ, аналог, схема певного фрагмента реальності, об’єкта культури або пізнання оригіналу; інтерпретація (в логіці, математиці) [1].

В. Штофф розглядає модель як подумки подану або реалізовану систему, яка відображаючи або відтворюючи об’єкт дослідження здатна заміщати його так, що її вивчення дає нову інформацію про цей об’єкт [2]. Моделі класифікують за різними критеріями. 3 позицій системного підходу, будьяку модель можна розглядати як систему, а систему, з точки зору Г. Серікова, можна розглядати в морфологічному, структурному, функціональному, генезизному аспектах [3].

Аналіз педагогічної літератури засвідчує, що процес моделювання широко застосовується в педагогіці й дидактиці. При цьому моделюванню підлягає як зміст освіти, так і навчальна діяльність. У педагогіці модель розглядається як система об'єктів або знаків, яка відтворює певні суттєві властивості системи-оригіналу, вона є узагальненим відображенням об’єкта, результатом абстрактного практичного досвіду, а не безпосереднім результатом експерименту.

На думку Є. Оганесяна, педагогічна модель повинна будуватися при дотриманні принципу подібності самої моделі і проектованого об’єкта, а отже, вона повинна охоплювати об’єкт у цілому за важливими і впізнаваними ознаками [4]. Водночас, як зазначають дослідники О. Недосека і С. Тарасова, педагогічна модель повинна прогнозувати ефективну зміну об’єкта [5].

Проблема моделювання педагогічного процесу знайшла відображення у науковому доробку вітчизняних науковців: О. Антонової, А. Алексюка, О. Березюка, I. Беха, В. Бондар, Г. Ващенко, С. Вітвицької, О. Рудницької, С. Гончаренко, О. Пєхоти, С. Сисоєвої, О. Ярошенко та інших.

Під педагогічною моделлю розуміємо систему, яка відображаючи реальний об’єКт дослідження здатна заміщати його в процесі вивчення. Для відображення цілісної картини досліджуваного процесу розроблено модель формування дослідницької компетентності майбутніх фельдшерів у процесі вивчення біологічних дисциплін, яку визначено як структурно-змістову. Розробляючи педагогічну модель, дійшли висновку, що проблема формування дослідницької компетентності майбутніх фельдшерів у процесі вивчення біологічних дисциплін є складною і різнобічною, яку потрібно розглядати з позицій декількох взаємопов’язаних наукових підходів, а саме: системного та компетентнісного.

Дослідницька компетентність є системним утворенням, у зв’язку з чим системний підхід до дослідження педагогічних явищ є базовим у запропонованому дослідженні. Проблему системного підходу у педагогіці досліджували: В. Беспалько [6], Ю. Конаржевский [7], Г. Серіков [3] та ін.

Оскільки розглядається формування дослідницької компетентності майбутніх фельдшерів у процесі вивчення біологічних дисциплін у ході професійної підготовки, згідно з системним підходом, кінцевим результатом цієї підготовки є розвиток майбутніх фельдшерів як суб’ єктів системи професійної освіти. Науковцями встановлено, що стратегічною метою професійної освіти є інтелектуальний, духовно-моральний і професійний розвиток студентів [8]. У зв’ язку з тим, що у запропонованому дослідженні розглядається процес формування дослідницької компетентності майбутніх фельдшерів у процесі вивчення біологічних дисциплін, зупинимося на інтелектуальному розвитку як меті професійної підготовки.

Відповідно до системного підходу, інтелектуальний розвиток майбутніх фельдшерів має забезпечувати три рівні засвоєння знань: перший рівень сприяє розвитку пам'яті та полягає в простому відтворенні отриманих знань. На цьому рівні реалізується алгоритм “сприйняття, розуміння, заучування, відтворення”. Другий рівень сприяє розвитку репродуктивного мислення і полягає у 
відтворенні отриманих знань за наявним зразком у типових ситуаціях. На цьому рівні використовується “операційний алгоритм” [8]. Операційний алгоритм складається 3 таких операцій, як: аналіз, діагноз, рішення, результат, аналіз. Третій рівень засвоєння знань передбачає творчий рівень інтелектуального розвитку і полягає в творчому відтворенні знань у нестандартній ситуації. Цей рівень передбачає формулювання проблеми, розробку робочої гіпотези, алгоритмів, спостереження і формулювання висновків. Цей рівень сприяє не тільки творчому розвитку особистості, а й активному формуванню дослідницької компетентності майбутніх фельдшерів.

Таким чином, моделювання педагогічного процесу запропонованого дослідження відповідно до концепції системного підходу гарантує розвиток у майбутніх фельдшерів дослідницької компетентності.

Компетентнісний підхід є органічним продовженням системного підходу. Важливим аспектом компетентнісного підходу є те, що він виступає в сучасному суспільстві основою підготовки конкурентоспроможних фахівців, затребуваних у швидкоплинних економічних умовах.

Компетентнісний підхід в освіті - орієнтація освіти на досягнення достатньо високого рівня знань, досвіду, обізнаності для здійснення діяльності та спілкування в різних галузях і сферах, може слугувати основою для перебудови освітнього процесу, подолання однобічно-предметної орієнтації навчального процесу.

На думку О. Пометун, компетентнісний підхід в освіті - це спрямованість освітнього процесу на формування й розвиток основних базових і предметних компетентностей особистості. Результатом такого процесу повинна стати сформованість загальної компетентності людини, що є сукупністю ключових компетентностей, інтегрованою характеристикою особистості [9].

Результати наукових пошуків вчених В. Лугового, М. Євтуха, В. Байденко, О. Глузмана, І. Зимньої, О. Овчарук, О. Пометун, О. Савченко, А. Хуторського та інших щодо сутності й характеру ключових компетентностей дають підстави визначити дослідницьку компетентність як ключову.

У системі ключових компетентностей закладено загальні напрями повноцінного особистісного i професійного функціонування фахівця та його зростання в сучасному суспільстві, що знаходить своє відображення в освітньо-кваліфікаційній характеристиці майбутнього фельдшера.
У вітчизняній педагогічній науці “компетентність” визначається як спроможність особистості сприймати індивідуальні та соціальні потреби та відповідати на них, кваліфіковано будувати діяльність в будь-якому напрямі, виконувати певні завдання або роботу (О. Овчарук, О. Пометун, О. Савченко) [9].

Сформованість цієї компетентності забезпечує особистості безперервний саморозвиток протягом всього життя у соціальній та професійній сферах, оскільки забезпечує оволодіння системними трансдисциплінарними знаннями методології та парадигматики наукового дослідження, вміння всебічно, критично, економно опрацьовувати найновішу інформацію та мобільно використовувати іï для розв’язання професійних задач [10].

Рівень підготовки фельдшера повинен відповідати галузевому стандарту вищої освіти України, в якому визначено класи завдань діяльності фахівця, що передбачає сформованість дослідницької компетентності. Це стереотипна, діагностична, евристична діяльність; види уміння: предметно-практичне, предметно-розумове, знаково-практичне, знаковорозумове; рівні сформованості уміння: здатність виконувати дію, спираючись на матеріальні носії інформації щодо неї, здатність виконувати дію, спираючись на постійний розумовий контроль без допомоги матеріальних носіїв інформації, здатність виконувати дію автоматично, на рівні навички; компетенції: соціально-особисті, загальнонаукові, інструментальні, загально-професійні, спеціалізовано-професійні [11].

Виходячи з вищевикладеного, формування дослідницької компетентності майбутніх фельдшерів у процесі вивчення біологічних дисциплін не стихійний, а керований і регульований процес, результативність та успішність якого залежать від певних педагогічних умов (рис. 1).

Під педагогічною умовою розуміємо зовнішню обставину, що істотно впливає на перебіг педагогічного процесу, тією чи іншою мірою свідомо сконструйованого педагогом, що передбачає досягнення певного результату [12].

Педагогічні умови формування дослідницької компетентності майбутніх фельдшерів у процесі вивчення біологічних дисциплін полягали в наступних положеннях: забезпечення дослідницької спрямованості змісту біологічних дисциплін; занурення майбутніх фельдшерів в активну позанавчальну проектно-дослідницьку діяльність; усвідомлення майбутніми фельдшерами на рівні 


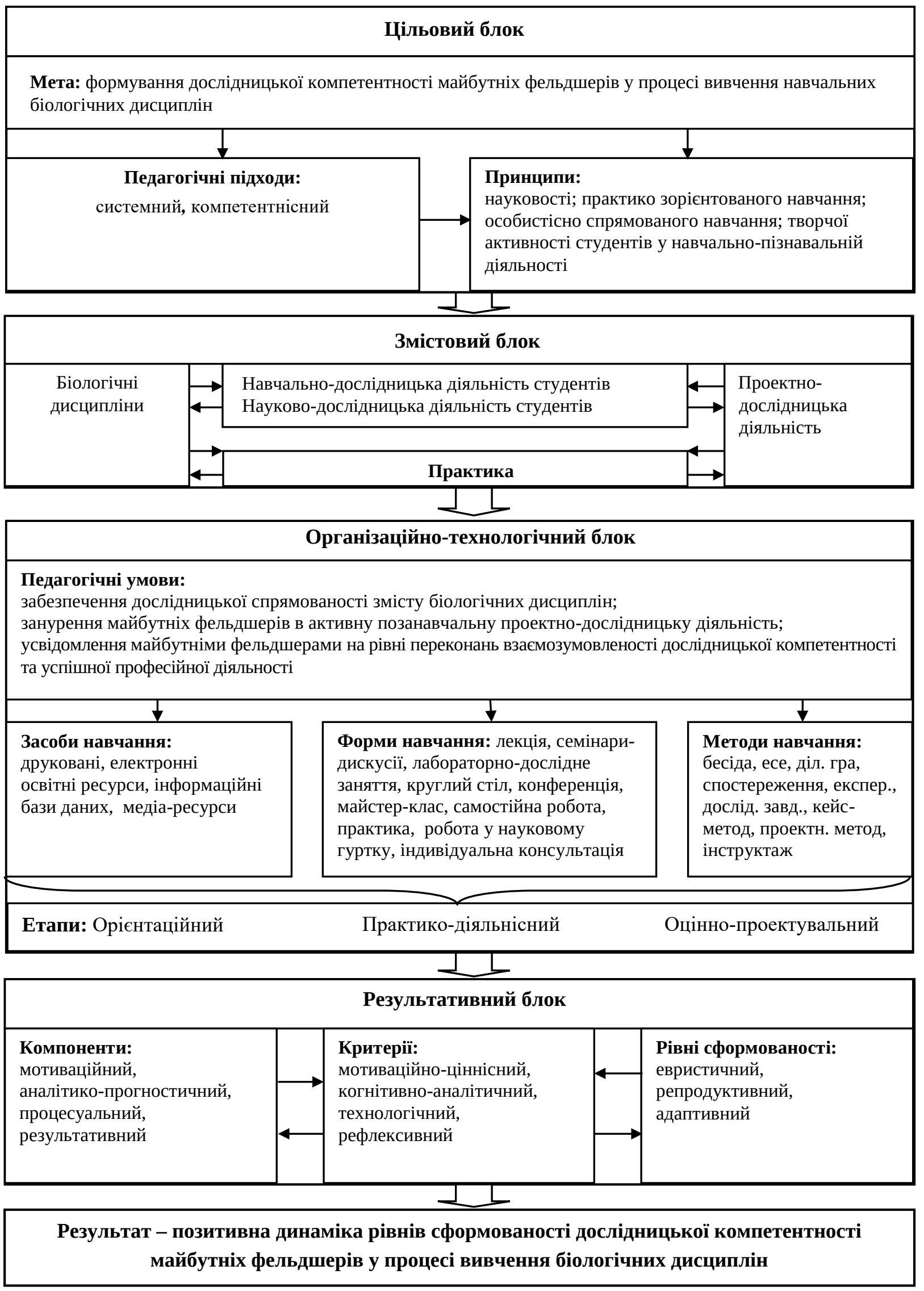

Рис. 1. Формування дослідницької компетентності майбутніх фельдшерів у процесі вивчення біологічних дисциплін. 
переконань значущості дослідницької компетентності для професійної діяльності.

Реалізація педагогічних умов можлива при підборі інструментарію, до якого входить низка засобів, методів і форм навчального процесу.

У межах запропонованого дослідження добір методів за класифікацією І. Лернера, М. Скаткіна вважаємо найбільш доцільним. Науковці, відповідно до концепції змісту освіти, методи навчання поділяють на інформаційно-рецептивні, репродуктивні, проблемного викладу, евристичні, дослідницькі. Автори вважають, що кожному елементу змісту освіти відповідають свої методи навчання. Вони визначають їх як систему послідовних дій педагогів, які організовують і обумовлюють пізнавальну і практичну діяльність тих, хто навчається, щодо засвоєння всіх елементів змісту освіти для досягнення цілей навчання [13].

Відтак, у дослідженні групи методів склали: методи, що формують науковий світогляд майбутніх фельдшерів і здійснюють обмін інформацією (бесіда, диспут, есе); методи, що організують дослідницьку діяльність майбутніх фельдшерів і стимулюючі їі мотиви (дослід, інструктаж, дослідницькі завдання, ділова гра, проектний метод, кейс-метод); методи, що надають допомогу майбутнім фельдшерам здійснювати рефлексію їх дослідницької діяльності (індивідуальна бесіда, есе).

Для ефективного формування дослідницької компетентності майбутніх фельдшерів у процесі вивчення навчальних біологічних дисциплін, керуючись навчальними програмами цих дисциплін, були відібрані основні форми організації навчання,

\section{Список літератури}

1. Непрокина И. В. Метод моделирования как основа педагогического исследования / И. В. Непрокина // Теория и практика общественного развития. - 2013. № 7. - Режим доступа : http://teoriapractica.ru/rus/files/ arhiv_zhurnala/2013/7/pedagogika/neprokina.pdf.

2. Штофф В. А. Моделирование и философия / В. А. Штофф. - М. : Наука, 1966. - 304 с.

3. Сериков Г. Р. Образование: аспекты системного отражения / Г. Р. Сериков. - Курган : Зауралье, 1997. 464 c.

4. Оганесян Е. В. Культурологическая модель педагогической практики в системе высшего педагогического образования : дисс. ... д-ра пед. наук: 13.00.08 / Е. В. Оганесян. - М., 2005. - 406 с.

5. Недосека О. Н. Педагогическая модель социальной адаптации студентов-педагогов к будущей профессио- а саме: лекції, семінари-дискусії, лабораторно-дослідні заняття, олімпіади, круглий стіл, конференція, майстер-клас, самостійна робота, практика, робота у науковому гуртку, індивідуальні консультації.

Отже, розроблену структурно-змістову модель формування дослідницької компетентності у процесі вивчення біологічних дисциплін утворюють чотири взаємопов'язаних блоки: цільовий, що включає мету з формування дослідницької компетентності в процесі вивчення біологічних дисциплін, домінуючі наукові підходи, принципи навчання в умовах медичного коледжу; змістовий, що відображає основні напрямки (зміст) навчально-дослідницької, науково-дослідницької діяльності; організаційно-технологічний, що включає педагогічні умови формування дослідницької компетентності, засоби, форми і методи педагогічної діяльності; результативний, що включає компоненти, критерії, показники та рівні сформованості дослідницької компетентності майбутніх фельдшерів (рис. 1).

Висновок. Моделювання процесу формування дослідницької компетентності відповідно до концепцій системного та компетентнісного підходів забезпечить позитивну динаміку рівнів сформованості дослідницької компетентності майбутніх фельдшерів.

Перспективи подальших досліджень. Подальший науковий пошук спрямовано на визначення ефективності розробленої моделі та педагогічних умов формування дослідницької компетентності майбутніх фельдшерів у процесі вивчення біологічних дисциплін.

нальной деятельности / О. Н. Недосека, С. М. Тарасова // Вектор науки ТГУ. - 2011. - № 3 (6). - С. 295-299.

6. Беспалько В. П. Основы теории педагогических систем (Проблемы и методы психолого-педагогического обеспечения технических обучающих систем) / В. П. Беспалько. - Воронеж : Изд-во ВГУ, 1997. - 304 с.

7. Конаржевский Ю. А. Что нужно знать директору школы о системе и системном подходе / Ю. А. Конаржевский. - Челябинск : Изд-во Челяб. гос. пед. ин-та, 1986. - 135 с.

8. Дворянкина Е. К. Цели и технологии развития субъектной позиции студентов в системе обучения / Е. К. Дворянкина // Мир науки, культуры, образования. - 2011. - № 3. - С. 31-33.

9. Компетентнісний підхід у сучасній освіті: світовий досвід та українські перспективи : Бібліотека 3 
освітньої політики : колективна монографія / [Н. М. Бібік, Л. М. Ващенко, О. І. Локшина та ін.] ; під заг. ред. О. В. Овчарук. - K. : K.I.C., 2004. - 112 с.

10. Бех I. Д. Компетентнісний підхід у сучасній освіті / І. Д. Бех // Вища освіта України. - 2009. - № 3 (додаток 1). Тематичний випуск “Педагогіка вищої школи: методологія, теорії, технології”. - С. 21-24.

11. Наказ МОЗ України № 401 від 07.07.2011 р. “Про введення в дію складових галузевих стандартів вищої освіти зі спеціальностей освітньо-кваліфікаційного рівня молодшого спеціаліста галузей знань “Медицина” та

\section{References}

1. Neprokina, I.V. (2013). Metod modelirovaniya kak osnova pedagogicheskogo issledovaniya [The method of modeling as a basis for pedagogical research]. Teoriya $i$ praktika obshchestvennogo razvitiia - Theory and Practice of Social Development, 7. Retrieved from: http://teoriapractica.ru/rus/files/arhiv_zhurnala/2013/7/pedagogika/ neprokina.pdf [in Russian].

2. Shtoff, V.A. (1966). Modelirovanie i filisofiya [Modeling and philosophy]. Moscow: Nauka [in Russian].

3. Serikov, G.R. (1997). Obrazovanie: aspekty sistemnogo otrazheniya [Education: aspects of system reflection]. Kurgan: Zauralie [in Russian].

4. Oganesian, E.V. (2005). Kulturologicheskaya model pedagogicheskoy praktiki $v$ sisteme vysshego pedagogicheskogo obrazovaniya: spetsyalnost: 13.00 .08 dis. ... d-ra ped. nauk [Culturological model of pedagogical practice in the system of higher pedagogical education: specialty: 13.00.08 thesis of Doctor of Pedagogical Sciences]. Moscow [in Russian].

5. Nedoseka, O.N., \& Tarasova, S.M. (2011). Pedagogicheskaya model sotsyalnoy adaptatsyi studentov-pedagogov $\mathrm{k}$ budushchey proffesionalnoy deyatelnosti [Pedagogical model of social adaptation of students-teachers to the future professional activity]. Vektor nauki TGU - Vector of Science of TGU, 3 (6), 295-299 [in Russian].

6. Bespalko, V.P. (1997). Osnovy teorii pedagogicheskikh sistem (Problemy i metody psikhologo-pedagogicheskogo obespecheniya tekhnicheskikh obuchayushchikh sistem) [Fundamentals of the theory of pedagogical systems (Problems and methods of psychological and pedagogical support of technical training systems)]. Voronezh: Publishing house VGU [in Russian].

7. Konarzhevskyi, Yu.A. (1986). Chto nuzhno znat direktoru shkoly o sisteme i sistemnom podkhode [What the principal need to know about the system and the system approach]. Chelyabinsk: Publishing house Chelyabinsk State Pedagogic University [in Russian].

8. Dvoriankina, E.K. (2011). Tseli i tekhnologii razvitiya subyektnoy positsii studentov v sisteme obucheniya [Goals
“Фармація”” [Електронний ресурс]. - Режим доступу : http://mozdocs.kiev.ua/view.php?id=12802.

12. Баженова Н. Г. Педагогические условия, ориентированные на развитие: теоретический аспект / Н. Г. Баженова, И. В. Хлудеева // Известия Российского государственного педагогического университета им. А. И. Герцена. - 2012. - № 151. - С. 217-223.

13. Лернер И. Классификация методов обучения / И. Лернер. - Режим доступа : https://murzim.ru/nauka/ pedagogika/didaktika/26920-klassifikaciya-metodovobucheniya-lerner-iya-skatkin-mn.html.

and technologies of development of subject position of students in the system of training]. Mir nauki, kultury, obrazovaniya - World of Science, Culture, Education, 3, 31-33 [in Russian].

9. Bibik, N.M., Vashchenko, L.M., Lokshyna, O.I., Ovcharuk, O.V., Parashchenko, L.I., Pometyn, O.I., \& Savchenko, O.Ya. (2004). Kompetentnisnyi pidkhid u suchasniy osviti: svitovyi dosvid ta ukrainski perspektyvy: Biblioteka z osvitnioi polityky: Kolektyvna monohrafiia [Competence approach in modern education: world experience and Ukrainian prospects: Library Educational Policy: Collective Monograph]. O. V. Ovcharuk (Ed.) Kyiv: “K.I.C.” [in Ukrainian].

10. Bekh, I.D. (2009). Kompetentnisnyi pidhid u suchasniy osviti [Competence approach in modern education]. Vyshcha osvita Ukrainy - Higher education of Ukraine, 3, 21-24 [in Ukrainian].

11. Nakaz MOZ Ukrainy №401 vid 07.07.2011 “Pro vvedennia v diiu skladovykh haluzevykh standartiv vyshchoi osvity zi spetsialnostei osvitnio-kvalifikatsiinoho rivnia molodshoho spetsialista haluzei znan "Medytsyna" ta"Farmatsiia"” [Order of the Ministry of Healthcare of Ukraine №401 from July 7, 2011. “On introduction of the components of the industry standards of higher education in the specialties of educational qualification of junior specialist of knowledge area "Medicine" and "Pharmacy"”] [Electronic source]. Retrieved from: http://mozdocs.kiev. ua/view.php?id=12802 [in Ukrainian].

12. Bazhenova, N.H., \& Khludeeva, I.V. (2012). Pedagogicheskie usloviya, oriyentirovannye na razvitie: teoreticheskiy aspect [Pedagogical conditions, oriented at development: theoretical aspect]. Izvestiya Rossiyskogo gosudarstvennogo pedagogicheskogo universiteta im. A.I. Gertsena - News of Russian State Pedagogical University by A.I. Gertsen, 151, 217-223 [in Russian].

13. Lerner I., Skatkin, M. Klassifikatsiya metodov obucheniya [Classification of teaching methods]. Retreived from: https:// murzim.ru/nauka/pedagogika/didaktika/26920-klassifikaciyametodov-obucheniya-lerner-iya-skatkin-mn.html [in Russian]. 